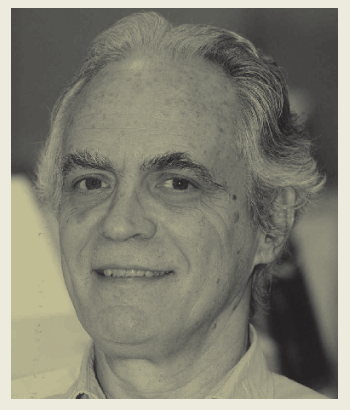

\title{
PERSPECTIVAS PARA 2022
}

A inflação e sua acompanhante inseparável, a taxa Selic, marcham velozmente em direção aos dois dígitos. Provavelmente, ambas as taxas irão inaugurar o ano eleitoral de 2022 acima dos $10 \%$, desencadeando perdas e danos e adiando uma vez mais a retomada do crescimento da economia.

A inflação representa uma maneira fácil de aumentar a arrecadação: os preços, sobre os quais os impostos são calculados, aumentam e a receita cresce, ao passo que despesas correntes do governo, como pagamento de salários (reajustes), não crescem com a mesma velocidade. Além disso, o aumento no valor das transações demanda, para efetuá-las (apesar do Pix), maior emissão de moeda: produzir nota de $\mathrm{R} \$ 100$ custa apenas $\mathrm{R} \$ 0,50$, sendo a diferença embolsada pelo emissor.

Se, por um lado, as receitas tributárias aumentam, por outro o governo lida com substância eleitoralmente tóxica: preços nas nuvens obrigam os mais pobres a comprar o osso, pois não é possível adquirir a carne que o envolve. E, entre a inanição e a revolta, o caminho é curto, mas, para neutralizar o desgosto, o governo acena com um auxílio de $\mathrm{R} \$ 400$, já que não é pecado abrir a caixa de ferramentas das bondades. A operação fura-teto, que viabiliza também as secretas emendas parlamentares, deve ser entendida neste contexto: o importante é ganhar as eleições, o resto fica para depois. Se a economia despenca arrastando ainda mais para o fundo do poço o emprego e a renda de milhões, a gente resolve em 2023.

É certo que até os ministros mais magros tendem a empurrar com a barriga, preferindo adiar ações desagradáveis hoje, mesmo que elas se tornem desastrosas amanhã. Cumprem ordens dos políticos, e a missão mais importante destes é garantir a reeleição. Esse filme se repete com frequência.

No médio e longo prazo, no entanto, essa política afugenta investidores. Sabemos que investimentos produtivos, indispensáveis para a retomada do crescimento, demandam tempo de maturação. Em outras palavras, requerem duração no mínimo de três a cinco anos para apresentar os primeiros retornos. Se os investidores não sentirem segurança e as incertezas aumentarem, permanecerão no modo de espera e a alavanca do crescimento não se moverá de forma robusta.

A manobra eleitoreira que o governo federal tenta com a operação fura-teto em nada contribui para apresentar um futuro razoavelmente estável. Ao contrário, ampliando a dívida pública, o governo federal necessitará rolar parte crescente dela no curto prazo, pagando juros cada vez mais elevados. As inevitáveis desvalorizações cambiais, ao mesmo tempo causa e efeito do ambiente envenenado pelo binômio inflação/incertezas, elevarão os preços da cesta básica, atormentando de maneira atroz a vida dos mais pobres.

Investidores permanecerão com o dinheiro empoçado, esperando o desenlace eleitoral de 2022, outro ano de provável recessão ou, na melhor das hipóteses, de crescimento raquítico.

Alternativa? Um dos caminhos para evitar o fura-teto seria lançar um imposto sobre a riqueza acumulada pelas famílias mais ricas - o sofrimento dos mais pobres seria mitigado sem desarrumar as contas públicas ou afetar o padrão de vida dos que vivem no topo da pirâmide. 